\title{
Public Sector Accounting in Europe: A Systematic Literature Review
}

\author{
Hélio Corguinho Fernandes ${ }^{1}$, João Lopes Pita ${ }^{1}$, José Domingues Jesus ${ }^{1} \&$ Guilherme Martins Camará ${ }^{1}$ \\ ${ }^{1}$ Portuguese Military Academy, Portugal \\ Correspondence: Hélio Corguinho Fernandes, Portuguese Military Academy, Portugal.
}

Received: January 7, 2021

Accepted: February 22, 2021

Online Published: March 31, 2021

doi:10.5430/ijfr.v12n4p88

URL: https://doi.org/10.5430/ijfr.v12n4p88

\begin{abstract}
There has been an increased interest in public sector accounting research due to the changing standards worldwide with harmonization on the horizon. Despite this trend, there is still a lack of comprehension of national and local governments' role in adopting and improving the international standards to enhance accountability, transparency and developing a more consistent and evolved society. This article aims to systematically review the literature on public accounting in European countries by examining the research trends.

The analysis is developed through a bibliometric study based on three keywords: "Public Sector", "Accounting", and "Europe". We systematically analyze the articles in the Web of Science database.

This work presents several articles through a bibliometric study based on defined keywords. To define the relationship between the articles and the most cited authors, we based the systematic analysis on the aggregation of articles by clusters.

In the last twenty years, public accounting in Europe has undergone significant changes, adapting to needs and innovations, which the most prominent resides in new accounting standards.

Adopting International Public Sector Accounting Standards can benefit countries that introduce them into their system, namely increasing the system's responsibility and transparency.

Research is inevitably limited by the impact of public accounting changes in Europe and governments' responses to social, economic and fiscal environments.
\end{abstract}

This systematic review shed light on the challenges that public management has faced recently.

Keywords: public accounting, Europe, systematic review

\section{Introduction}

This research work comprises a study around the characterization of Public Accounting research in Europe through the analysis of studies published in various scientific journals of reference of the object to be treated.

The analysis and good management of public accounting have always been crucial for sustaining, surviving and overcoming the adversities and challenges that countries face daily.

The search for qualitative and quantitative information on government action, and the increase in discontent on the part of public sector users, led to several changes in Public Accounting in Europe and the adoption of practices based on private management.

According to Grybauskaitè (2020), Commissioner responsible for Financial Programming and the Budget, having high-quality financial information is essential for effective management in the public sector.

Since the end of the 1980s, the public sector in Europe has undergone radical organizational reform. Changes aimed to improve the efficiency, effectiveness and accountability of all sectors, looking for international harmonization of public accounting (Monteiro et al., 2015).

The various political and institutional pressures, namely from financing entities and the European Union (EU), have driven this change a little across all European countries, namely in continental Europe (Lapsley et al., 2009; Gomes et al., 2014; Oulasvirta, 2014).

The international public accounting standards (IPSAS), based on the adoption of accrual accounting (accrual regime), constitute the various countries' primary reference. Thus, the main changes introduced have been strongly influenced 
by the accounting standards and principles adopted in the private sector, namely, adopting the accrual regime.

This article focuses on the dimensions of accounting, accountability, and legitimacy associated with the "changes in governance" of current societies and deepening public sector accounting standards in Europe. Our study also aims at how the New Public Management audit technologies are reshaping the work environment and what effects they have caused. We will also understand the need for harmonizing public sector accounting in the EU.

\section{Public Accounting - Brief Review}

The search for qualitative and quantitative information on government action, and the increase in discontent on the part of public sector users, led to several changes in Public Accounting in Europe and the adoption of practices based on private management.

This change in thinking was also caused and influenced by the public debt crisis in 2009 that affected many countries in the Eurozone, forcing them to reflect on how they presented accounting and financial results. This European crisis forced the intervention of external entities such as the International Monetary Fund (IMF), emphasizing the need to reformulate and harmonize the Public Sector's budget and accounting systems.

In this sense, motivated by the public debt crisis, it was necessary to regulate some European countries' public finances, through measures and policies, all to improve the public deficit and achieve better budgetary strength, with the role of the IMF being crucial.

Currently, greater control over public finances by international authorities is required to prevent past incidents.

\subsection{Public Accounting in Europe}

Over the past 30 years, there has been a wave of reforms in government and public sector accounting systems. The New Public Financial Management (NPFM), refers to the reforms introduced in the systems, procedures, organizations, and legislation. Some of the purposes are to obtain and effectively use public financial resources, which cover expenses and revenues and debt in the context of the public budget, accounting, internal and external control, and financial reports (Guthrie et al., 2003).

So NPFM has supported these modernization efforts, focusing mainly on the implementation of Accrual Based Accounting. This new system moves to a new accrual accounting system. This model recognizes "generating facts" instead of cash transfers and seeking convergence with the business accounting model.

Despite the concerns and criticisms, the adoption of accrual accounting is widely seen as a transparent process (Lapsley et al., 2009) and unstoppable (Pina et al., 2009). According to Lapsley et al. (2009), the choice to adopt international principles based on accrual accounting is mainly determined in the political sphere and not by technical or management arguments.

In addition to accounting, governments have budget reports that still play a prominent role in public sector decision making. In many countries, budgeting plays a more important role than financial reporting (Heiling et al., 2013). In most European countries, cash accounting still remains at the centre of the budget process (Brusca et al., 2015).

\subsection{Recent Research and Efforts to Harmonize Public Sector Accounting}

The idea of harmonizing and standardizing accounting has been put forward for many years in the public sector, although relatively more recently than in the private sector.

Nobes (2012, p. 75), defines harmonization as "a process of increasing the compatibility of accounting practices, establishing limits to their degree of variation", while normalization "seems to imply working towards a more rigid and narrow".

According to Ferreira (2014), implementing uniform and comparable practices on an accrual basis for all Public Administration sectors is crucial for the harmonization of accounting systems following International Public Sector Accounting Standards. To this end, the State must have information systems and management tools suitable for the standard application of a single Official Plan of Accounts consistent with the principles of IPSAS.

The standardization concept has been used mainly to describe how national standards establish mandatory requirements for groups of entities (for example, companies or public sector entities). In contrast, harmonization is typically used in the international field to portray a process of continuous adjustments to accounting principles and similar accounting documents (Caperchione, 2015). 


\subsection{The Need for Harmonized Public Sector Accounting in the European Union}

Among the advantages of international harmonization, almost all standards highlight the highest transparency and accountability levels as the main benefits. This is because a standard set of accounting principles will be easily understood by professionals and auditors (Ball, 2012).

The main benefits of harmonizing public sector accounting in the EU are:

- A transparent and standard accounting field for all public sector entities to provide accurate information.

- Publication of comparable and audited government financial statements in a format compatible with international standards that market players can easily understand. Higher quality accounting information is also expected to lower capital cost; this was the private sector case (see Li, 2010; Florou \& Kosi, 2015).

\subsection{Divergences Between Public Accounting and National Accounting}

National Accounting aims to record the flows of goods and services and distribution and financial operations that allow an analysis (through measurement) of a country's economic situation.

Public Accounting aims to enable accountability, legality control and the provision of information for decision making. The two accounting systems' analysis allows us to verify that they present common points and some differences (Nogueira, 2007).

Due to the evolution of the structures of the modern economies of the countries that integrate the Economic and Monetary Union (EMU), it was necessary to change the current SEC, to obtain comparable, updated, reliable. It harmonized information on the structure of the economy and each Member State (Ferreira, 2014).

\section{Methodology}

Through a bibliometric study based on three keywords defined initially, Public Sector, Accounting and Europe, we systematically analyzed the Web of Science database articles. This platform was chosen because it is the principal repository for public accounting and management articles. It provides results that can later be used in tools such as Harzing Public or Perish (HPP) and VOSviewer.

In our research, we use three filters to focus our work on the desired area. Table 1 summarises the filters used as well as the result of articles found after them.

Table 1. Filters application

\begin{tabular}{lll}
\hline \multicolumn{2}{l}{ Web Of Science on October 23, 2020 } & Nr Entries \\
\hline 1st Filter & $\mathrm{AB}=$ account* AND AB=public sector* & 6009 \\
\hline 2nd Filter & $\mathrm{TI}=$ account* AND AB=public sector* & 815 \\
\hline 3rd Filter & $\mathrm{TI}=$ account* AND AB=public sector* AND ALL=europe* & 125 \\
\hline
\end{tabular}

\subsection{Articles Relationship}

Based on the result obtained with the repository, the results were used to use the HPP tool to find the ten articles best classified according to the same, based on the number of citations for each article per year. This criterion was considered in order to be able to equate articles dating from older years with more recent articles. Table 2 reflects the result, in which we also present the conclusions of the selected articles.

Table 2. Review output by article

\begin{tabular}{|c|c|c|c|c|}
\hline Author & Article & Focus & Method & Finding \\
\hline $\begin{array}{l}\text { Kersbergen } \\
\& \quad \text { Waarden } \\
(2004)\end{array}$ & $\begin{array}{l}\text { 'Governance' as } \\
\text { a bridge } \\
\text { between } \\
\text { disciplines: } \\
\text { Cross-disciplina } \\
\text { ry inspiration } \\
\text { regarding shifts }\end{array}$ & $\begin{array}{l}\text { It focuses on the study } \\
\text { of the common concern } \\
\text { with the problems of } \\
\text { governance, } \\
\text { responsibility and, } \\
\text { therefore, } \\
\text { legitimacy associated }\end{array}$ & $\begin{array}{l}\text { Document } \\
\text { analysis }\end{array}$ & $\begin{array}{l}\text { In order to gain a complete } \\
\text { understanding of "changes } \\
\text { in governance", political } \\
\text { science needs a much } \\
\text { stronger multidisciplinary } \\
\text { orientation, covering } \\
\text { politics, law, public }\end{array}$ \\
\hline
\end{tabular}




\begin{tabular}{|c|c|c|c|c|}
\hline & $\begin{array}{l}\text { in governance } \\
\text { and problems of } \\
\text { governability, } \\
\text { accountability } \\
\text { and legitimacy }\end{array}$ & $\begin{array}{l}\text { with "changes in } \\
\text { governance" in today's } \\
\text { societies }\end{array}$ & & $\begin{array}{l}\text { administration, economics } \\
\text { and } \\
\text { administration, as well as } \\
\text { sociology, geography and } \\
\text { history. }\end{array}$ \\
\hline Shore (2008) & $\begin{array}{l}\text { Audit culture } \\
\text { and Illiberal } \\
\text { governance } \\
\text { Universities and } \\
\text { the politics of } \\
\text { accountability }\end{array}$ & $\begin{array}{l}\text { How are New Public } \\
\text { Management audit } \\
\text { technologies reshaping } \\
\text { the work environment } \\
\text { and their effects on } \\
\text { academic behaviour? }\end{array}$ & $\begin{array}{l}\text { It is based on } \\
\text { examples from } \\
\text { the } \quad \text { UK, } \\
\text { especially } \\
\text { post-1990 } \\
\text { university } \\
\text { reform }\end{array}$ & $\begin{array}{l}\text { The economic imperatives } \\
\text { of neoliberalism, combined } \\
\text { with New Public } \\
\text { Management technologies, } \\
\text { have produced profound } \\
\text { changes in the workplace's } \\
\text { organization in many } \\
\text { contemporary capitalist } \\
\text { societies. }\end{array}$ \\
\hline
\end{tabular}

\begin{tabular}{|c|c|c|c|c|}
\hline $\begin{array}{l}\text { Rossi et al. } \\
(2016)\end{array}$ & $\begin{array}{l}\text { Harmonizing } \\
\text { public sector } \\
\text { accounting in } \\
\text { Europe: } \\
\text { thinking out of } \\
\text { the box }\end{array}$ & $\begin{array}{l}\text { Debate on the } \\
\text { harmonization of public } \\
\text { sector accounting } \\
\text { standards in Europe. } \\
\text { The authors present } \\
\text { arguments favouring } \\
\text { harmonization, } \\
\text { recognizing the } \\
\text { pluralism and the } \\
\text { existing diversity, } \\
\text { taking stock of the } \\
\text { situation in } 14 \\
\text { European countries. }\end{array}$ & $\begin{array}{l}\text { Case } \\
\text { analysis }\end{array}$ & $\begin{array}{l}\text { The article proposes a way } \\
\text { forward for policymakers. } \\
\text { It standardizes where } \\
\text { harmonization benefits can } \\
\text { be obtained without } \\
\text { forcing EU member } \\
\text { countries to abandon their } \\
\text { current public sector } \\
\text { accounting systems } \\
\text { necessarily. }\end{array}$ \\
\hline $\begin{array}{l}\text { Perry } \\
\text { Nölke } \\
(2006)\end{array}$ & $\begin{array}{l}\text { The political } \\
\text { economy of } \\
\text { International } \\
\text { Accounting } \\
\text { Standards }\end{array}$ & $\begin{array}{l}\text { This article defends the } \\
\text { introduction of fair } \\
\text { value accounting by the } \\
\text { IASB reflects and } \\
\text { reinforces the altered } \\
\text { production relations. } \\
\text { The financial sector } \\
\text { increasingly dominates } \\
\text { the productive sector, } \\
\text { nationally } \\
\text { institutionalized } \\
\text { economic systems are } \\
\text { undermined. New } \\
\text { forms of economic } \\
\text { appropriation are } \\
\text { validated. }\end{array}$ & $\begin{array}{l}\text { Document } \\
\text { analysis }\end{array}$ & $\begin{array}{l}\text { Accounting techniques } \\
\text { cannot be reduced to } \\
\text { questions of efficiency, } \\
\text { since they propose to } \\
\text { quantify and compare } \\
\text { things that, by their very } \\
\text { nature, are neither } \\
\text { quantifiable nor directly } \\
\text { comparable. }\end{array}$ \\
\hline $\begin{array}{l}\text { Bracci et al. } \\
(2015)\end{array}$ & $\begin{array}{l}\text { Public sector } \\
\text { accounting, } \\
\text { accountability } \\
\text { and austerity: } \\
\text { more than } \\
\text { balancing the } \\
\text { books? }\end{array}$ & $\begin{array}{l}\text { The purpose of this } \\
\text { article is to consider } \\
\text { how public sector } \\
\text { accountability and } \\
\text { accountability systems } \\
\text { are involved in the } \\
\text { development and } \\
\text { implementation of } \\
\text { austerity policies. } \\
\text { Besides, there are } \\
\text { several issues that }\end{array}$ & $\begin{array}{l}\text { Interdisciplinar } \\
\text { y literature } \\
\text { review. } \\
\text { Discussion of } \\
\text { the changing } \\
\text { nature of public } \\
\text { sector } \\
\text { accounting } \\
\text { practices under } \\
\text { austerity. }\end{array}$ & $\begin{array}{l}\text { Reports of austerity in the } \\
\text { field of public sector } \\
\text { accounting research have } \\
\text { been worryingly limited. } \\
\text { This article addresses the } \\
\text { shortcomings, revealing } \\
\text { some critical implications } \\
\text { and challenges of austerity } \\
\text { policies for public sector } \\
\text { accounting research. }\end{array}$ \\
\hline
\end{tabular}


accounting researchers need to address on the subject of accounting for austerity.

\begin{tabular}{ll}
\hline & \\
& \\
& Has \\
Hopper \& $\begin{array}{l}\text { Management } \\
\text { Accounting } \\
\text { Bui (2016) } \\
\text { Research been } \\
\text { critical? }\end{array}$
\end{tabular}

This article examines the contributions that Management

Accounting Research (MAR) has made - and has not made, to social and critical analysis of MAR in the 25 years since its launch.
Seven were

evaluated in social and critical analysis:

"Relevance

Lost" and new costs;

reconstitute the

public sector;

social and

environmental

accounting; and

the change in

the geography

of time and

space between

European and

American

research.
The article concludes that MAR has made substantial contributions to social and critical accounting (broadly defined), but not in critical areas, striving to give a more excellent voice and influence to society's marginalized sectors worldwide.

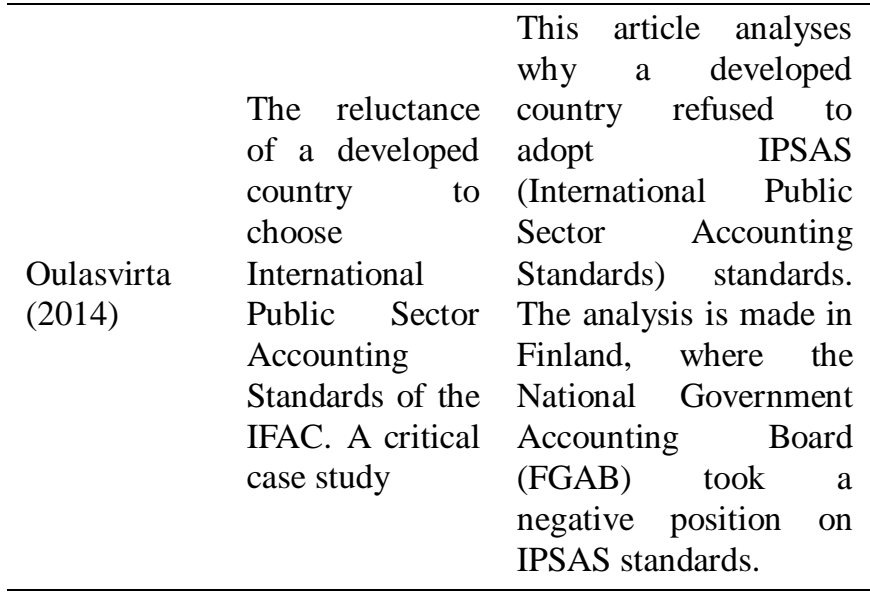

$\begin{array}{ll} & \text { How CFOs } \\ & \text { Determine } \\ \text { Management } \\ \text { Naranjo-Gil } & \text { Accounting } \\ \text { et al. (2009) } & \text { Innovation: An } \\ & \text { Examination of } \\ & \text { Direct and } \\ & \text { Indirect Effects }\end{array}$

Examine the role of the $\mathrm{CFO}$ in the innovation of MAS (management accounting systems).
Interviews and

participant

observation at

FGAB.
The article describes the reasons for FGAB's decision and presents an interpretation supported by institutional theory.

\begin{tabular}{|c|c|}
\hline $\begin{array}{l}\text { They compared } \\
\text { the effects of } \\
\text { strategy and } \\
\text { historical } \\
\text { performance on } \\
\text { MAS adoption } \\
\text { for } \\
\text { organizations } \\
\text { with different } \\
\text { types of CFOs. } \\
\text { They tested } \\
\text { hypotheses by } \\
\text { combining } \\
\text { public health } \\
\text { sector files and } \\
\text { research data in } \\
\text { Spain. }\end{array}$ & $\begin{array}{l}\text { Individual differences } \\
\text { between CFOs are } \\
\text { predictive of organizations' } \\
\text { use of MAS. Besides, they } \\
\text { proposed that the CFO's } \\
\text { characteristics moderate } \\
\text { the extent to which } \\
\text { organizations rationally } \\
\text { adapt to (environmental) } \\
\text { contingencies. }\end{array}$ \\
\hline
\end{tabular}




\begin{tabular}{|c|c|c|c|c|}
\hline (2019) & $\begin{array}{l}\text { government } \\
\text { administration } \\
\text { systems and } \\
\text { local } \\
\text { government } \\
\text { accounting } \\
\text { information } \\
\text { needs: is there a } \\
\text { mismatch? }\end{array}$ & $\begin{array}{l}\text { study on the } \\
\text { relationships between } \\
\text { the local government's } \\
\text { administrative systems } \\
\text { and the local } \\
\text { government's } \\
\text { information needs in a } \\
\text { sample of European } \\
\text { countries, characterized } \\
\text { by a legalistic } \\
\text { orientation. }\end{array}$ & $\begin{array}{l}\text { literature and } \\
\text { data gathered } \\
\text { through a } \\
\text { questionnaire, } \\
\text { conducted an } \\
\text { exploratory } \\
\text { study }\end{array}$ & $\begin{array}{l}\text { a mismatch between the } \\
\text { required accounting and } \\
\text { performance measurement } \\
\text { information for internal } \\
\text { and external purposes } \\
\text { assessed based on the } \\
\text { current administrative } \\
\text { system and the accounting } \\
\text { and performance } \\
\text { measurement information } \\
\text { required by law for } \\
\text { decision making and } \\
\text { performance of bills }\end{array}$ \\
\hline $\begin{array}{l}\text { Peters et al. } \\
(2010)\end{array}$ & $\begin{array}{l}\text { Accounting for } \\
\text { water use in } \\
\text { Australian red } \\
\text { meat production }\end{array}$ & $\begin{array}{l}\text { The study aims to solve } \\
\text { inventories' problems } \\
\text { failing to demonstrate } \\
\text { environmental impacts } \\
\text { and water abuse in } \\
\text { agriculture. } \\
\text { The authors intend to } \\
\text { classify the water life } \\
\text { cycle inventory (LCI) } \\
\text { data in the Australian } \\
\text { red meat sector } \\
\text { consistent } \\
\text { contemporary with } \\
\text { definitions } \\
\text { sustainability to solve } \\
\text { the problem. }\end{array}$ & $\begin{array}{l}\text { They studied } \\
\text { the water used } \\
\text { by three red } \\
\text { meat supply } \\
\text { systems in } \\
\text { southern } \\
\text { Australia and } \\
\text { analyzed the } \\
\text { inflow and } \\
\text { outflow of } \\
\text { goods and } \\
\text { services } \\
\text { purchased by } \\
\text { the properties. }\end{array}$ & $\begin{array}{l}\text { The main hydrological } \\
\text { flows in the system are } \\
\text { precipitation and } \\
\text { evapotranspiration. The } \\
\text { flows and funds of water } \\
\text { transferred represent small } \\
\text { components of the total } \\
\text { water inflows for the } \\
\text { agricultural enterprise. The } \\
\text { proportion of degraded } \\
\text { water is also small } \\
\text { concerning the water } \\
\text { returned pure to the } \\
\text { atmosphere. }\end{array}$ \\
\hline $\begin{array}{l}\text { Brusca et al. } \\
(2013)\end{array}$ & $\begin{array}{l}\text { Legitimating } \\
\text { International } \\
\text { Public Sector } \\
\text { Accounting } \\
\text { Standards } \\
\text { (IPSAS): the } \\
\text { case of Spain. }\end{array}$ & $\begin{array}{l}\text { Analysis of growth in } \\
\text { the adoption of } \\
\text { International Public } \\
\text { Sector Accounting } \\
\text { Standards (IPSAS) } \\
\text { worldwide has focused } \\
\text { on Anglo-Saxon } \\
\text { countries. So, this } \\
\text { document considers the } \\
\text { implications } \\
\text { adopting IPSAS in } \\
\text { Spain. }\end{array}$ & $\begin{array}{l}\text { Document } \\
\text { analysis }\end{array}$ & $\begin{array}{l}\text { A combination of factors: } \\
\text { the political need to } \\
\text { demonstrate improvements } \\
\text { in the public sector, } \\
\text { accountability, governance } \\
\text { systems based on the } \\
\text { "code of law", European } \\
\text { Union pressure to } \\
\text { harmonize business } \\
\text { accounting and the } \\
\text { credibility resulting from } \\
\text { the adoption of IPSAS by } \\
\text { the central international } \\
\text { institutions, contributed to } \\
\text { their legitimation in Spain. }\end{array}$ \\
\hline $\begin{array}{l}\text { Brusca } \\
\text { Martínez } \\
\text { (2016) }\end{array}$ & $\begin{array}{l}\text { Adopting } \\
\text { International } \\
\text { Public Sector } \\
\text { Accounting } \\
\text { Standards: a } \\
\text { challenge for } \\
\text { modernizing } \\
\text { and harmonizing } \\
\text { public sector }\end{array}$ & $\begin{array}{l}\text { This article aims to } \\
\text { analyze the incentives } \\
\text { and barriers to adopting } \\
\text { International Public } \\
\text { Sector Accounting } \\
\text { Standards and their } \\
\text { main benefits, using a } \\
\text { structural equation } \\
\text { model. }\end{array}$ & $\begin{array}{l}\text { A questionnaire } \\
\text { applied to the } \\
\text { American and } \\
\text { European Union } \\
\text { countries used } \\
\text { to build a } \\
\text { structural } \\
\text { model. }\end{array}$ & $\begin{array}{l}\text { This article shows us that } \\
\text { the introduction of the } \\
\text { International Public Sector } \\
\text { Accounting Standards can } \\
\text { have many advantages in } \\
\text { practice. The countries that } \\
\text { have implemented these } \\
\text { standards consider that } \\
\text { they allow an increase in } \\
\text { transparency and }\end{array}$ \\
\hline
\end{tabular}




\begin{tabular}{|c|c|c|c|c|}
\hline & accounting. & & & accountability. \\
\hline $\begin{array}{l}\text { Dalgaard et } \\
\text { al. (2006) }\end{array}$ & $\begin{array}{l}\text { Modelling } \\
\text { representative } \\
\text { and coherent } \\
\text { Danish farm } \\
\text { types based on } \\
\text { farm } \\
\text { accountancy } \\
\text { data for use in } \\
\text { environmental } \\
\text { assessments }\end{array}$ & $\begin{array}{l}\text { The purpose of this } \\
\text { study was to establish a } \\
\text { national agricultural } \\
\text { model to estimate data } \\
\text { on the use of resources, } \\
\text { production and } \\
\text { environmentally } \\
\text { significant emissions } \\
\text { for a set of } \\
\text { representative types of } \\
\text { agricultural holdings. }\end{array}$ & $\begin{array}{l}\text { A statistical } \\
\text { weighting } \\
\text { method used to } \\
\text { divide the farm } \\
\text { accounts into } \\
\text { farm types } \\
\text { ensures } \\
\text { representativity } \\
\text { of each farm } \\
\text { type, }\end{array}$ & $\begin{array}{l}\text { In short, methane } \\
\text { emissions were higher in } \\
\text { dairy farms than all other } \\
\text { types of farms. In general, } \\
\text { conventional dairy farms } \\
\text { emitted more nitrate, } \\
\text { ammonia, and nitrous } \\
\text { oxide than organic dairy } \\
\text { farms. }\end{array}$ \\
\hline $\begin{array}{l}\text { Arnaboldi \& } \\
\text { Lapsley } \\
(2009)\end{array}$ & $\begin{array}{l}\text { On the } \\
\text { Implementation } \\
\text { of Accrual } \\
\text { Accounting: A } \\
\text { Study of } \\
\text { Conflict and } \\
\text { Ambiguity }\end{array}$ & $\begin{array}{l}\text { This document focuses } \\
\text { on the study of the } \\
\text { implementation of } \\
\text { accrual accounting in } \\
\text { the local government. } \\
\text { This issue is examined } \\
\text { from an implementation } \\
\text { perspective. } \\
\text { implementation The } \\
\text { perspective adopted is } \\
\text { based on Matland's } \\
\text { (1995) } \\
\text { ambiguity-conflict } \\
\text { model. }\end{array}$ & $\begin{array}{l}\text { Combined } \\
\text { methods } \\
\text { approach: } \\
\text { analysis of } \\
\text { documents and } \\
\text { public debates; } \\
\text { a survey of } \\
\text { capital } \\
\text { accountants of } \\
\text { local authorities } \\
\text { and case study } \\
\text { information on } \\
\text { management's } \\
\text { perceptions of } \\
\text { this accounting } \\
\text { information }\end{array}$ & $\begin{array}{l}\text { This investigation reveals a } \\
\text { complex result of the } \\
\text { reformers' initiatives that } \\
\text { retained these accounting } \\
\text { changes within the } \\
\text { accounting domain. That } \\
\text { had a limited impact on the } \\
\text { potential, more } \\
\text { comprehensive users of } \\
\text { this information. }\end{array}$ \\
\hline $\begin{array}{l}\text { Cohen et al. } \\
(2015)\end{array}$ & $\begin{array}{l}\text { Accounting for } \\
\text { austerity: the } \\
\text { Troika in the } \\
\text { Eurozone. }\end{array}$ & $\begin{array}{l}\text { This document aims to } \\
\text { examine the impact of } \\
\text { the Eurozone financial } \\
\text { crisis, discussing } \\
\text { Greece, Ireland, and } \\
\text { Spain's experiences. It } \\
\text { examines, in particular } \\
\text { the Troika's influence } \\
\text { and actions in } \\
\text { managing the Eurozone } \\
\text { sovereign debt crisis. }\end{array}$ & $\begin{array}{l}\text { Source of } \\
\text { information for } \\
\text { this study has } \\
\text { been: } \\
\text { documents from } \\
\text { Greek, Irish and } \\
\text { Spanish } \\
\text { governments } \\
\text { and reports } \\
\text { from EU and } \\
\text { IMF bodies, } \\
\text { complemented } \\
\text { by media } \\
\text { coverage, as } \\
\text { deemed appropriate }\end{array}$ & $\begin{array}{l}\text { It offers an insight into its } \\
\text { significance in explaining } \\
\text { the dramatic influence of } \\
\text { austerity programs in the } \\
\text { Eurozone. }\end{array}$ \\
\hline $\begin{array}{l}\text { Tasan-Kok } \\
\text { et al. (2019) }\end{array}$ & $\begin{array}{l}\text { Changing public } \\
\text { accountability } \\
\text { mechanisms in } \\
\text { the governance } \\
\text { of Dutch urban } \\
\text { regeneration. }\end{array}$ & $\begin{array}{l}\text { This article unveils the } \\
\text { influence of conflicting } \\
\text { dynamics on urban } \\
\text { planning practices' } \\
\text { foundations, focusing } \\
\text { on changing public } \\
\text { accountability } \\
\text { mechanisms created } \\
\text { through contractual } \\
\text { relationships between } \\
\text { public and private }\end{array}$ & $\begin{array}{l}\text { Content } \\
\text { analysis } \\
\text { contractual } \\
\text { data. }\end{array}$ & $\begin{array}{l}\text { It was concluded that } \\
\text { accountability had changed } \\
\text { hands between actors in } \\
\text { the public and private } \\
\text { sectors, and } \\
\text { responsibilities are defined } \\
\text { in each Project through } \\
\text { different measures and } \\
\text { tools. }\end{array}$ \\
\hline
\end{tabular}


sector agencies.

\begin{tabular}{|c|c|c|c|c|}
\hline $\begin{array}{l}\text { Bianchi } \\
(2010)\end{array}$ & $\begin{array}{l}\text { Improving } \\
\text { Performance } \\
\text { and Fostering } \\
\text { accountability in } \\
\text { the Public } \\
\text { Sector through } \\
\text { System } \\
\text { Dynamics } \\
\text { Modelling: } \\
\text { From 'External' to an } \\
\text { 'Internal' } \\
\text { Perspective. }\end{array}$ & $\begin{array}{l}\text { This article aims to } \\
\text { outline the benefits that } \\
\text { justify an approach } \\
\text { adapted to the } \\
\text { modelling of Systems } \\
\text { Dynamics (SD) in the } \\
\text { public sector, to } \\
\text { improve performance } \\
\text { and promote } \\
\text { decision-makers' } \\
\text { accountability. }\end{array}$ & $\begin{array}{l}\text { Two case } \\
\text { studies were } \\
\text { analyzed: 1- a } \\
\text { dynamic } \\
\text { resource-based } \\
\text { view (DRBV } \\
2-\quad \text { SD } \\
\text { modelling based } \\
\text { on DRBV. }\end{array}$ & $\begin{array}{l}\text { The need to combine an } \\
\text { "internal" perspective with } \\
\text { an "external" perspective } \\
\text { (about decision-makers) in } \\
\text { the development of SD } \\
\text { models is claimed. } \\
\text { Different levels of } \\
\text { intervention are discussed } \\
\text { (ie, macro, micro and } \\
\text { meso). }\end{array}$ \\
\hline $\begin{array}{l}\text { Pina } \\
\text { Torres } \\
(2003)\end{array}$ & $\begin{array}{l}\text { Reshaping } \\
\text { public sector } \\
\text { accounting: An } \\
\text { international } \\
\text { comparative } \\
\text { view }\end{array}$ & $\begin{array}{l}\text { The purpose of this } \\
\text { document is to study } \\
\text { the government } \\
\text { accounting changes } \\
\text { carried out in } 16 \\
\text { member countries of } \\
\text { the Organization for } \\
\text { Economic Coordination } \\
\text { and Development } \\
\text { (OECD) and the } \\
\text { European Community, } \\
\text { taking as reference the } \\
\text { International Public } \\
\text { Sector Accounting } \\
\text { Standards (IPSAS). }\end{array}$ & $\begin{array}{l}\text { Use of the } \\
\text { central } \\
\text { government's } \\
\text { financial } \\
\text { reports. }\end{array}$ & $\begin{array}{l}\text { The study shows that } \\
\text { between the extremes of } \\
\text { cash accounting and total } \\
\text { accrual accounting, the } \\
\text { countries studied have } \\
\text { implemented numerous } \\
\text { intermediate variants. The } \\
\text { developments in accrual } \\
\text { accounting seem to be } \\
\text { more related to New } \\
\text { Public Management } \\
\text { (NPM) initiatives than the } \\
\text { cultural categories studied. }\end{array}$ \\
\hline $\begin{array}{l}\text { Goodin } \\
(2003)\end{array}$ & $\begin{array}{l}\text { Democratic } \\
\text { accountability: } \\
\text { The } \\
\text { distinctiveness } \\
\text { of the third } \\
\text { sector. }\end{array}$ & $\begin{array}{l}\text { Demonstrate that the } \\
\text { State, the market and } \\
\text { the voluntary non-profit } \\
\text { sectors can be seen as } \\
\text { being each } \\
\text { characterized by a } \\
\text { different regime of } \\
\text { responsibility. }\end{array}$ & & $\begin{array}{l}\text { It was concluded that the } \\
\text { different regimes could } \\
\text { complement each other, } \\
\text { reinforcing the democratic } \\
\text { accountability. They can } \\
\text { also subdue each other if } \\
\text { their differences are not } \\
\text { respected. }\end{array}$ \\
\hline $\begin{array}{l}\text { Helden et al. } \\
(2008)\end{array}$ & $\begin{array}{l}\text { Distinctive } \\
\text { research } \\
\text { patterns on } \\
\text { public sector } \\
\text { performance } \\
\text { measurement } \\
\text { (PSPM) of } \\
\text { public } \\
\text { administration } \\
\text { and accounting } \\
\text { disciplines. }\end{array}$ & $\begin{array}{l}\text { This assumption } \\
\text { explores distinct } \\
\text { patterns of investigation } \\
\text { in public administration } \\
\text { and accounting } \\
\text { disciplines related to } \\
\text { the measurement of } \\
\text { public sector } \\
\text { performance }\end{array}$ & Case studies. & 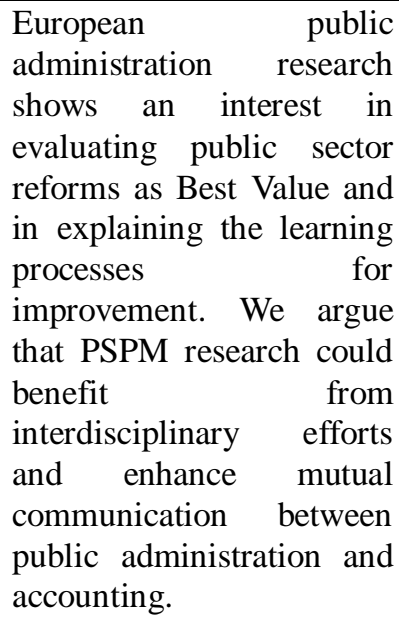 \\
\hline
\end{tabular}


Among the selection of studies correspondent to the filters' application, there were highlighted the 20 articles published in journals with more impact factor and presented in Table 2.

IPSAS are a legacy of the public sector's continuous transformation, especially the financial and report areas in which the NPM has produced profound changes in many contemporary capitalist societies (Shore, 2008). The NPM policies are also related to accrual accounting (Pina \& Torres, 2003), in line with strengthening the relationship with citizens and increasing accountability culture. Cohen et al. (2018) reinforce the role of the accounting information and performance measurement information for decision-making and accountability, warning the risks of mismatch between the needed information for internal and external purposes of the administrative system.

Despite the recognized pluralism and diversity among European countries, Rossi et al. (2016) defend the harmonizing public sector accounting in Europe, allowing more transparency and accountability. These goals can be reached without the countries abdicate their particular public sector accounting systems. On the other hand, it is necessary to beware of systems where the budget is fundamental to the public accounting system. That is visible, for instance, in Spain, Greece and Ireland (European Commission, 2013) or in Finland (Oulasvirta, 2013), which can constitute a risk to the implementation of IPSAS.

So, Bracci et al. (2015) pretend to determine if accounting systems are destined to be used as engines for growth and for thinking about public service responsibilities. Budget and cost-control are essential stones in the public finance administrations; nonetheless, accounting systems should be more socially inclusive.

To respond to the new challenges that the information society demands, Helden et al. (2008) defend that public administration and accounting could benefit from interdisciplinary efforts and enhance mutual communication. In that way, academics have a role to play true the research of civil society involvement, the public interest and political economy, without neglect social and environmental accounting (Hopper \& Bui, 2016).

\subsection{Relations Between Authors}

European public administration research shows an interest in evaluating public sector reforms as Best Value and explaining the learning processes for improvement. We argue that PSPM research could benefit from interdisciplinary efforts and enhance mutual communication between public administration and accounting.

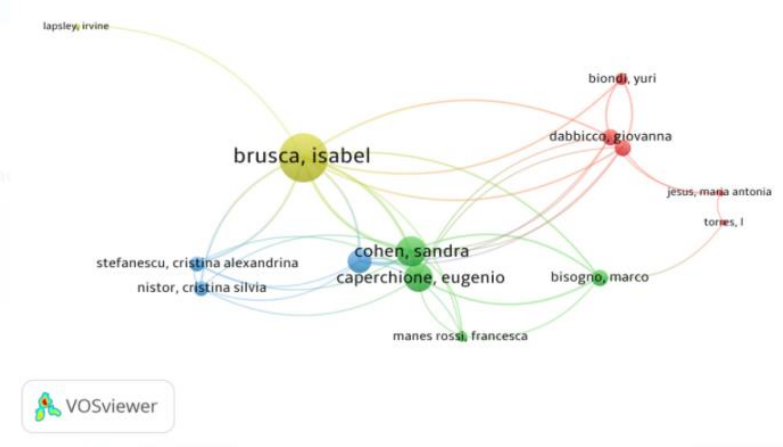

Figure 1. Relationship between the most cited authors

In Figure 1, the author Isabel Brusca stands out from all the other authors because she presents the most cited works and co-authored several articles with some of the authors presented in the cluster aggregation. According to the Publish or Perish platform, the author's articles that stand out the most in terms of publications per year are: "Harmonizing public sector accounting in Europe: thinking out of the box" (2016) and "Local government administration systems and local government accounting information needs: is there a mismatch?" (2019).

Brusca \& Martínez (2016) argue that the adoption of IPSAS contributes to increased transparency and accountability in the public sector. However, for Cohen et al. (2018), the assurance of transparency needs more effort in local governments. Only sporadically the accounting and measurement information suits the needs created by the different levels of financial and organizational autonomy of local government administration systems. 
Brusca et al. (2013) resumed the combination of factors to result in the central institutions' adoption of IPSAS. With accountability and transparency ahead, it is also prominent the European Union's pressure to harmonize accounting and that the process itself of adopting IPSAS be reliable.

\section{Conclusions}

There is a strong correlation centred on one author responsible for the connection between several clusters. Isabel Brusca reinforces an idea of the general scope of themes. Thus, it is essential to reiterate the contribution to this concept of public accounting in Europe. We can refer to the author Isabel Brusca's statements as the "Great Contributions", which in a way integrates the most cited key ideas and encompass the four categories defined above as clusters.

In short, the main contributions suggest a guiding thread that will be able to formulate standardization policies, through which there will be added value in harmonizing public accounting. In the European context, it is desirable to achieve this objective with measures that do not require the acceding countries to adopt new public accounting systems. Another contribution is the notion of a possible adoption of IPSAS.

This study has limitations that are also common to other research due to the methodology requiring specific time considerations. The major disadvantage of a systematic literature review with bibliometric analysis is that it requires considerably more effort than traditional literature reviews. The limitation of the chosen systematic review methodology lies in its rigor and accuracy of the cluster linkage method.

We have made a way to understanding public accounting in Europe in the last 20 years and the importance of IPSAS to transparency and accountability. However, the closer we lean, the more density we see. Simplifying the complexity of policies and actual needs of all benefits from public accounting is essential.

Researchers in the future must provide a more comprehensible set up of the win-win relations between the public and private sectors in favor of better policies. Second, future research should explore the reasons for some delays in the European space for adopting IPSAS.

\section{References}

Arnaboldi, M., \& Lapsley, I. (2009). On the implementation of accrual accounting: a study of conflict and ambiguity. European Accounting Review, 18(4), 809-836. https://doi.org/10.1080/09638180903136225

Ball, I. (2012). New development: transparency in the public sector. Public Money \& Management, 32(1), 35-40. https://doi.org/10.1080/09540962.2012.643054

Bianchi, C. (2010). Improving performance and fostering accountability in the public sector through system dynamics modelling: from an 'external' to an 'internal' perspective. Systems Research and Behavioral Science, 27(4), 361-384. https://doi.org/10.1002/sres.1038

Bracci, E., Humphrey, C., Moll, J., \& Steccolini, I. (2015). Public sector accounting, accountability and austerity: more than balancing the books?. Accounting, Auditing \& Accountability Journal. https://doi.org/10.1108/AAAJ-06-2015-2090

Brusca, I., \& Martínez, J. C. (2016). Adopting international public sector accounting standards: A challenge for modernizing and harmonizing public sector accounting. International Review of Administrative Sciences, 82(4), 724-744. https://doi.org/10.1177/0020852315600232

Brusca, I., Montesinos, V., \& Chow, D. S. (2013). Legitimating international public sector accounting standards (IPSAS): the case of Spain. Public Money \& Management, 33(6), 437-444. https://doi.org/10.1080/09540962.2013.836006

Caperchione, E. (2015). Standard setting in the public sector: State of the art. In Public sector accounting and auditing in Europe (pp. 1-11). Palgrave Macmillan, London. https://doi.org/10.1057/9781137461346_1

Cohen, S., Guillamón, M. D., Lapsley, I., \& Robbins, G. (2015). Accounting for austerity: the Troika in the Eurozone. Accounting, Auditing \& Accountability Journal, 28(6), 966-992. https://doi.org/10.1108/AAAJ-04-2014-1668

Cohen, S., Manes Rossi, F., Caperchione, E., \& Brusca, I. (2019). Local government administration systems and local government accounting information needs: is there a mismatch?. International Review of Administrative Sciences, 85(4), 708-725. https://doi.org/10.1177/0020852317748732 
Dalgaard, R., Halberg, N., Kristensen, I. S., \& Larsen, I. (2006). Modelling representative and coherent Danish farm types based on farm accountancy data for use in environmental assessments. Agriculture, Ecosystems \& Environment, 117(4), 223-237. https://doi.org/10.1016/j.agee.2006.04.002

Ernst \& Young. (2012). Overview and comparison of public accounting and auditing practices in the 27 EU member states. Report prepared for Eurostat.

Ferreira, C. (2014). Harmonização contabilística no sector público: constrangimentos na adopção das IPSAS. Doctoral dissertation, Instituto Superior de Ciências Sociais e Políticas. Retrieved from https://www.repository.utl.pt/bitstream/10400.5/6552/1/Dissertac\%CC\%A7a\%CC\%83o_Carla\%20Ferreira_jan 2014.pdf

Florou, A., \& Kosi, U. (2015). Does mandatory IFRS adoption facilitate debt financing?. Review of Accounting Studies, 20(4), 1407-1456. https://doi.org/10.1007/s11142-015-9325-z

Goodin, R. E. (2003). Democratic accountability: The distinctiveness of the third sector. Archives Européennes de Sociologie/European Journal of Sociology/Europäisches Archiv für Soziologie, 359-396. https://doi.org/10.1017/S0003975603001322

Guthrie, J., Parker, L., \& English, L. M. (2003). A review of new public financial management change in Australia. Australian Accounting Review, 13(30), 3-9. https://doi.org/10.1111/j.1835-2561.2003.tb00393.x

Heiling, J., Schührer, S., \& Chan, J. L. (2013). New development: Towards a grand convergence? International proposals for aligning government budgets, accounts and finance statistics. Public Money \& Management, 33(4), 297-303. https://doi.org/10.1080/09540962.2013.799838

Hopper, T., \& Bui, B. (2016). Has management accounting research been critical?. Management Accounting Research, 31, 10-30. https://doi.org/10.1016/j.mar.2015.08.001

Jan van Helden, G., Johnsen, A., \& Vakkuri, J. (2008). Distinctive research patterns on public sector performance measurement of public administration and accounting disciplines. Public Management Review, 10(5), 641-651. https://doi.org/10.1080/14719030802264366

Kersbergen, K. V., \& Waarden, F. V. (2004). 'Governance'as a bridge between disciplines: Cross-disciplinary inspiration regarding shifts in governance and problems of governability, accountability and legitimacy. European Journal of Political Research, 43(2), 143-171. https://doi.org/10.1111/j.1475-6765.2004.00149.x

Lapsley, I., Mussari, R., \& Paulsson, G. (2009). On the adoption of accrual accounting in the public sector: a self-evident and problematic reform. https://doi.org/10.1080/09638180903334960

Naranjo-Gil, D., Maas, V. S., \& Hartmann, F. G. (2009). How CFOs determine management accounting innovation: an examination of direct and indirect effects. European Accounting Review, 18(4), 667-695. https://doi.org/10.1080/09638180802627795

Nobes, C. (2012). International harmonisation. In C. Nobes, \& R. Parker (Eds.), Comparative International Accounting (Pearson).

Nogueira, S., \& Ribeiro, N. (2007). Divergências entre contabilidade pública e contabilidade nacional: análise às contas da administraçao pública portuguesa. In Conocimiento, innovación y emprendedores: camino al futuro ( $\mathrm{p}$. 61). Universidad de La Rioja.

Oulasvirta, L. (2014). The reluctance of a developed country to choose International Public Sector Accounting Standards of the IFAC. A critical case study. Critical Perspectives on Accounting, 25(3), 272-285. https://doi.org/10.1016/j.cpa.2012.12.001

Perry, J., \& Nölke, A. (2006). The political economy of international accounting standards. Review of International Political Economy, 13(4), 559-586. https://doi.org/10.1080/09692290600839790

Peters, G. M., Wiedemann, S. G., Rowley, H. V., \& Tucker, R. W. (2010). Accounting for water use in Australian red meat production. The International Journal of Life Cycle Assessment, 15(3), 311-320. https://doi.org/10.1007/s11367-010-0161-x

Pina, V., \& Torres, L. (2003). Reshaping public sector accounting: an international comparative view. Canadian Journal of Administrative Sciences/Revue Canadienne des Sciences de l'Administration, 20(4), 334-350. https://doi.org/10.1111/j.1936-4490.2003.tb00709.x 
Pina, V., Torres, L., \& Yetano, A. (2009). Accrual accounting in EU local governments: One method, several approaches. European Accounting Review, 18(4), 765-807. https://doi.org/10.1080/09638180903118694

Rodrigues, L. L. (2012). Portugal rumo às normas internacionais de contabilidade pública. AECA: Revista de la Asociación Española de Contabilidad y Administración de Empresas, (99), 68-71.

Rossi, F., Cohen, S., Caperchione, E., \& Brusca, I. (2016). Harmonizing public sector accounting in Europe: thinking out of the box. Public Money \& Management, 36(3), 189-196. https://doi.org/10.1080/09540962.2016.1133976

Shore, C. (2008). Audit culture and illiberal governance: Universities and the politics of accountability. Anthropological Theory, 8(3), 278-298. https://doi.org/10.1177/1463499608093815

Tasan-Kok, T., Hurk, M., Özogul, S., \& Bittencourt, S. (2019). Changing public accountability mechanisms in the governance of Dutch urban regeneration. European Planning Studies, 27(6), 1107-1128. https://doi.org/10.1080/09654313.2019.1598017

\section{Copyrights}

Copyright for this article is retained by the author(s), with first publication rights granted to the journal.

This is an open-access article distributed under the terms and conditions of the Creative Commons Attribution license (http://creativecommons.org/licenses/by/4.0/). 